\title{
Epidermólise bolhosa albopapulóide (variante de Pasini)*
}

\section{Albopapuloid Epidermolysis Bullosa (Pasini's Variant)*}

\author{
Letícia Pereira Spinelli \\ Celso Sodré
}

\author{
Renata Rodrigues Orofino \\ Rubem David Azulay ${ }^{\dagger}$
}

\author{
Bernard Kawa Kac
}

Resumo: A epidermólise bolhosa albopapulóide é doença rara, de caráter autossômico dominante, também conhecida como epidermólise bolhosa distrófica albopapulóide de Pasini.

Os autores relatam o caso de uma paciente de 37 anos de idade, com início do quadro aos sete anos, com lesões bolhosas e milia nas áreas de traumatismo, além de máculas hipocrômicas e atróficas (lesões albopapulóides) no corpo. A paciente também apresenta pele apergaminhada, xerótica, e distrofia ungueal dos pés. A histopatologia da lesão bolhosa revelou clivagem subepidérmica, compatível com o diagnóstico clínico.

Palavras-chave: epidermólise bolhosa; epidermólise bolhosa distrófica.

\begin{abstract}
Summary: Albopapuloid epidermolysis bullosa (Pasini's variant) is a rare, autosomal dominant inherited disorder.

The authors report the case of a 37-year-old female patient with blisters on trauma areas, atrophic macules (albopapuloid lesions) and milia, with onset of disease at age seven. The histopathological exam of the blister reveals a subepidermal cleavage.

Key words: epidermolysis bullosa; epidermolysis bullosa dystrophica.
\end{abstract}

\section{INTRODUÇÃO}

A epidermólise bolhosa albopapulóide (EBD-AP) é afecção rara, de caráter autossômico dominante. ${ }^{1}$ É classificada no grupo das epidermóises bolhosas distróficas (EBD), que são mecanobuloses cicatriciais com típica formação de bolhas induzidas pelo traumatismo, cujo plano de clivagem ocorre abaixo da lâmina basal, como resultado de um defeito no colágeno tipo VII das fibrilas de ancoragem, resultante de uma mutação no gene COL7A1 ${ }^{2,3}$ A EBD comumente tem caráter dominante $\mathrm{e}$, menos freqüentemente, recessivo. ${ }^{1}$

As mutações no subtipo dominante da EBD envolvem a substituição da glicina por outro aminoácido na tripla hélice do gene COL7A1. Tais mutações impedem a produ-

\section{INTRODUCTION}

Albopapuloid epidermolysis bullosa (AP-DEB) is a rare, autosomal dominant disorder. ${ }^{I}$ It is classified in the group of dystrophic epidermolysis bullosas (DEB). They are cicatricial mechanobullous disorders with typical blister formation induced by traumatism. Its cleavage plane occurs below the basal lamina as the outcome of a defect in collagen type VII of the anchoring fibrils, resulting from a mutation in gene COL7A 1., Commonly, EB has a dominant trait. Less frequently, it is recessive. ${ }^{1}$

Mutations of the DEB dominant subtype involve substitution of glycine by other amino acids in the triple helix of gene COL7A1. Such mutations prevent the normal pro-

\footnotetext{
Recebido em 11.03.2002. / Received in March, $11^{\text {th }}$ of 2002.

Aprovado pelo Conselho Consultivo e aceito para publicação em 18.03.2003. / Approved by the Consultive Council and accepted for publication in March, $18^{\text {h }}$ of 2003.

* Trabalho realizado na Santa Casa De Misericórdia Do Rio De Janeiro - Instituto De Dermatologia - Chefia Do Prof. Dr. Rubem David Azulay. / Work done at "Santa Casa de

Misericórdia", Rio de Janeiro - Dermatology Institute - Head: Dr. Rubem David Azulay.

${ }^{1}$ Alunas do curso de Pós-Graduação do Instituto de Dermatologia Prof. Rubem David Azulay, da Santa Casa de Misericórida de Rio de Janeiro. / Medical students from the Post-Graduate Program at the Instituto de Dermatologia Prof. Rubem David Azulay of the Santa Casa de Misericórdia of Rio de Janeiro

Professor do curso de Pós-Graduação em Dermatologia da Santa Casa de Misericórdia do Rio de Janeiro e Chefe do Setor de Histopatologia. / Professor of Dermatology, the Postgraduate Program in Dermatology, Santa Casa de Misericórdia, Rio de Janeiro, and Head of the Histopathology Sector.

Professor do Curso de Pós-Graduação em Dermatologia Prof. Rubem David Azulay, Santa Casa de Misericórdia do Rio de Janeiro e Professor Adjunto do Serviço de Dermatologia, HUCFF-UFRJ, Universidade Federal do Rio de Janeiro./ Professor of the Post-Graduate Dermatology Program Prof. Rubem David Azulay of the Santa Casa de Misericordia of Rio de Janeiro and Assistant Professor of the Dermatology Service, HUCFF-UFRJ, Federal University of Rio de Janeiro.

${ }^{4}$ Chefe do Instituto de Dermatologia da Santa Casa de Misericórdia do Rio de Janeiro. Professor Emérito da UFRJ e Uff. Professor Titular da UGF e da Fte Souza Marques. / Head of the Dermatology Institute, Santa Casa de Misericórdia, Rio de Janeiro; Emeritus Professor, UFRJ and UFF; Titular Professor, UGF and Fte Souza Marques
} 
ção normal do colágeno tipo VII pelos queratinócitos basais, causando uma alteração nas fibrilas de ancoragem, com conseqüente fragilidade da junção dermo-epidérmica. Variações dessas mutações podem ocorrer dentro de uma mesma família e entre famílias diferentes de pacientes. ${ }^{3}$

A EBD dominante pode ser dividida em duas formas clínicas, segundo a presença ou ausência de lesões albopapulóides: as variantes de Pasini e Cockayne-Touraine, respectivamente. ${ }^{4,5}$

A análise histopatológica das lesões albopapulóides demonstrou proeminente proliferação de bandas de colágeno imaturo e deposição de material amorfo. ${ }^{5}$ Outros autores demonstraram a presença de proteoglicanos dermatan-sulfato degradados na derme papilar e subpapilar. ${ }^{6}$

\section{RELATO DO CASO}

Paciente do sexo feminino, 37 anos, branca, natural da Paraíba, residente no Rio de Janeiro.

Relata início do quadro aos sete anos de idade, com o surgimento de pápulas eritêmato-pruriginosas e bolhas em áreas de traumatismo, que ao involuírem deixavam máculas hipocrômicas e atróficas, e milia, de forma generalizada na pele, com exceção da face, região palmoplantar e unhas das mãos.

Na história patológica pregressa e familiar não havia nada digno de nota.

Ao exame dermatológico observavam-se bolhas flácidas, algumas já em involução, nos joelhos, dorso dos pés, terceiro pododáctilo esquerdo e cotovelo esquerdo; máculas hipocrômicas e atróficas no tronco e membros. Pele apergaminhada e atrófica em todo o corpo, com exceção da face. Milia no dorso da mão direita e face interna da coxa direita. Distrofia ungueal de todos os pododáctilos. Lesões pápulo-eritematosas na face interna das coxas (Figuras 1, 2, 3 e 4).

O exame histopatológico revelou a presença de

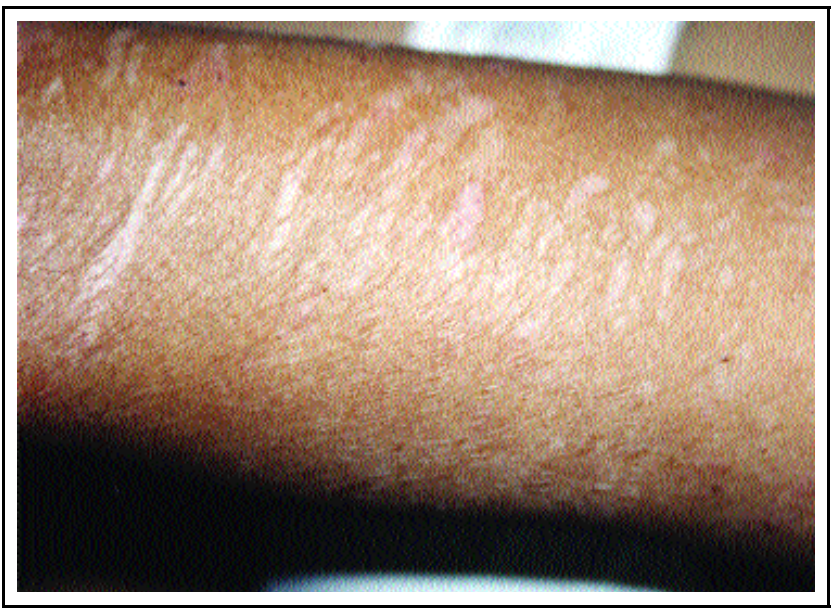

Figura 1: Lesões albopapulóides no antebraço direito. Figure 1: Albopapuloid lesions on the right forearm. duction of collagen type VII by basal keratinocytes, causing an alteration of the anchoring fibrils. The result is fragility of the dermoepidermal junction. Variations of the mutations may occur within a single family and among different families of patients. ${ }^{3}$

Dominant DEB may be divided into two clinical forms, according to the presence or absence of albopapuloid lesions: Pasini's variants and Cockayne-Touraine, respectively. ${ }^{4,5}$

Histopathologic analysis of the albopapuloid lesions demonstrates the prominent proliferation of immature collagen strips and amorphous material deposits. ${ }^{5}$ Other authors have demonstrated the presence of degraded dermatan sulphate proteoglycans in the papillary and subpapillary dermis. ${ }^{6}$

\section{CASE REPORT}

A 37-year-old Caucasian female, originally from Paraiba State and residing in Rio de Janeiro.

The patient reported that onset of the condition occurred at age seven, with emergence of erythematous pruriginous papules and blisters in trauma areas. In the course of their progression, the papules left hypochromic and atrophic macules and milia on the skin generally, with the exception of the face, palmoplantar region and fingernails.

Regarding the anterior and family pathological background there was nothing worth mentioning.

During the dermatological examination, flaccid blisters were observed, some of which were already in progression on the knees, dorsal aspect of the feet, third left toe and left elbow; hypochromic and atrophic macules on the trunk and limbs. The skin was chaffed and atrophic throughout the body, except for the face. Milia were observed on the dorsal aspect of the right hand and internal surface of the right thigh. Dystrophy of the nails appeared on each toe. Erythematous and papulous lesions on the internal surface of the thigh were also observed. (Figures 1, 2, 3 and 4).

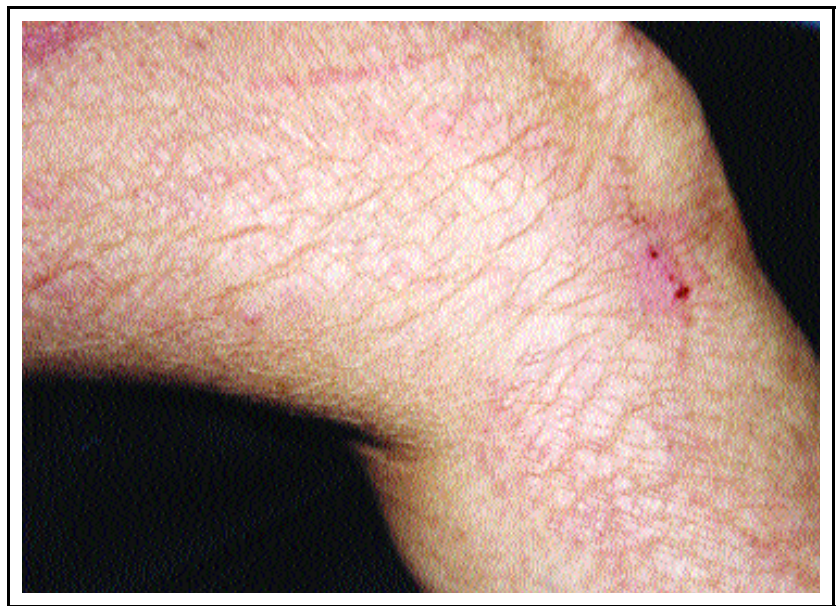

Figura 2: Notam-se a pele apergaminhada e a presença de milia na face interna da coxa e perna esquerdas. / Figure 2: Observe the chaffed skin and presence of milia on the inside surface of the left thigh and leg. 


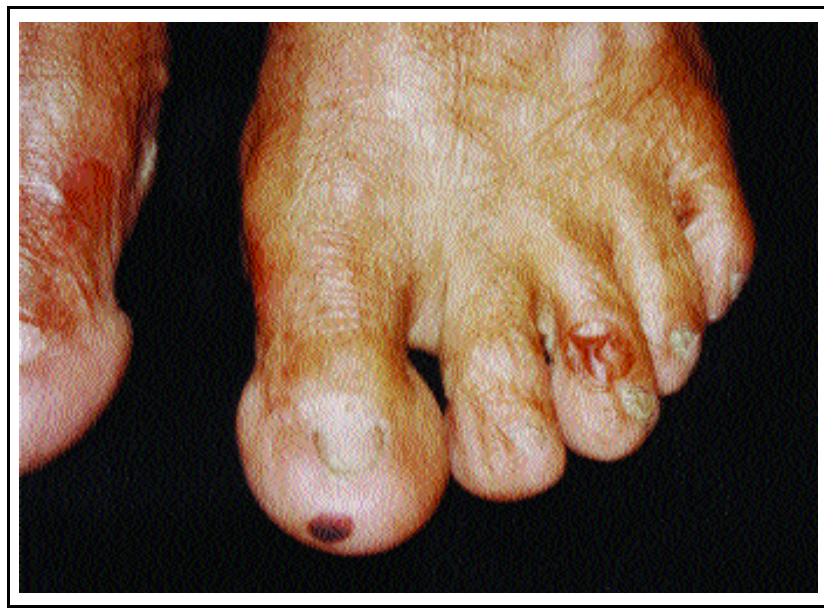

Figura 3: Distrofia ungueal nos pés, com a presença de bolhas pós-traumatismo no primeiro e terceiro pododáctilos esquerdos. Figure 3: Dystrophy of the toenail, with presence of posttraumatic blisters on the first and third left toes.

bolha subepidérmica, cujo conteúdo era constituído por eritrócitos, fibrina e escasso infiltrado linfocítico. $\mathrm{Na}$ derme papilar subjacente observava-se um infiltrado inflamatório misto, composto por neutrófilos, eosinófilos, linfócitos, melanófagos e siderófagos. Esses achados são compatíveis com o diagnóstico de epidermólise bolhosa (Figuras 5 e 6).

A terapêutica instituída foi vitamina $\mathrm{E}, 800 \mathrm{mg} / \mathrm{dia}$, via oral, e emolientes tópicos, com melhora parcial da qualidade da pele dos membros superiores, após dois meses de tratamento.

\section{DISCUSSÃO}

A EBD albopapulóide (EBD-AP) foi primeiramente descrita em 1928 por Pasini. $^{7}$ No Brasil, o primeiro caso observado foi em 1937, em São Paulo, por Cerruti, e o

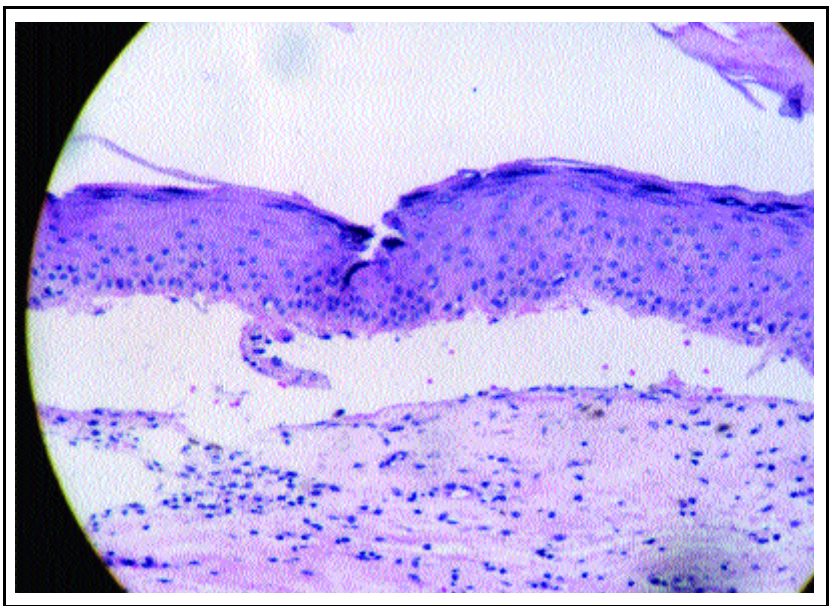

Figura 5: Bolha subepidérmica com escassas hemácias e infiltrado inflamatório na derme papilar (H\&E 40x).

Figure 5: Subepidermal blister with rare red blood cells and inflammatory infiltrate on the papillary dermis ( $H$ and $E 40 x$ ).

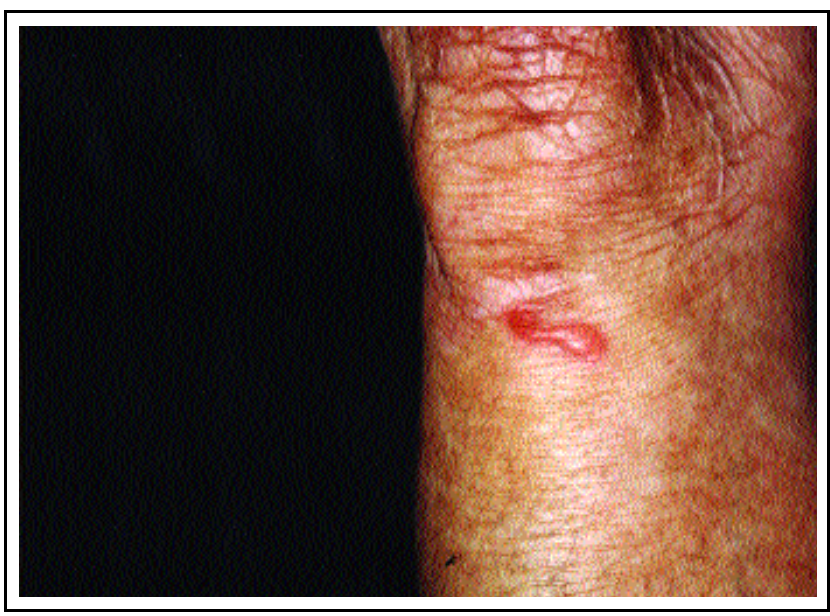

Figura 4: Observam-se a pele atrófica da perna direita e bolha infrapatelar.

Figure 4: Observe the atrophic skin on the right leg and infrapatellar blister.

The histopathologic examination revealed the presence of subepidermal blisters consisting of erythrocytes, fibrin and rare lymphocytic infiltrate. In the subjacent papillary dermis a mixed inflammatory infiltrate could be observed, consisting of neutrophils, eosinophils, lymphocytes, melanophages and siderophages. These findings were compatible with the diagnosis of epidermolysis bullosa (Figures 5 and 6).

The therapy instituted was with vitamin E, $800 \mathrm{mg}$ daily taken orally, and topical emollients. There was partial improvement in skin quality of the upper limbs after three months of treatment.

\section{DISCUSSION}

Albopapuloid DEB (AP-DEB) was first described by Pasini in 1928.7 In Brazil, the first observed case dates back to 1937 by Cerruti in São Paulo. The second case was

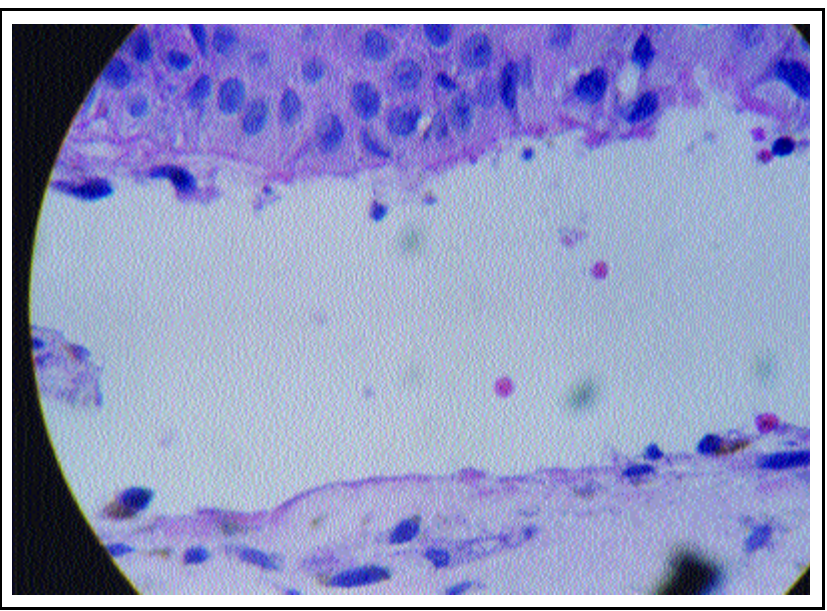

Figura 6: Observa-se depósito de fibrina e hemácias no interior da bolha (H\&E 400x).

Figure 6: Observe the fibrin deposit and red blood cells on the inside of the blister ( $H$ and $E 400 X$ ). 
segundo caso foi descrito na literatura brasileira em 1941 por Silva. ${ }^{8}$

As lesões são caracterizadas pela formação de bolhas, cicatrizes e múltiplas pápulas brancas pruriginosas. As bolhas ocorrem principalmente nas extremidades após mínimos traumatismos. No processo de cicatrização das bolhas há o surgimento de milia e lesões atróficas. ${ }^{9}$ As pápulas desenvolvem-se na adolescência, podendo ocorrer mais precocemente, predominando no tronco (região lombossacra) e extremidades, independentes do aparecimento das bolhas. ${ }^{2,10}$ São lesões firmes, perifoliculares, de coloração marfim, de até 15 milímetros de diâmetro, sem involução espontânea. ${ }^{10}$ No caso relatado a paciente possuía as lesões albopapulóides desde a infância, além das bolhas (após traumatismo) e das lesões cicatriciais.

Podem ocorrer erosões orais e/ou esofageanas, não cicatriciais, ${ }^{2,9} \mathrm{o}$ que não foi observado no caso descrito.

Apesar de não ocorrerem alterações dentárias, as unhas podem ser distróficas ou ausentes. ${ }^{29}$ A paciente em questão só apresentava alteração nas unhas dos pododáctilos.

Embora a expectativa de vida seja normal, o carcinoma espinocelular pode desenvolver-se nas áreas distróficas. ${ }^{2}$ No caso, não havia lesões sugestivas de malignidade ao exame físico.

A histopatologia da lesão bolhosa revela apenas uma bolha subepidérmica, ${ }^{11,12}$ como visto no caso.

Muitas alterações ultra-estruturais nas fibrilas de ancoragem têm sido previamente relatadas na EBD, embora nenhuma delas tenha sido específica de um subtipo da EBD. Na forma albopapulóide de Pasini as fibrilas de ancoragem apresentam anormalidades quantitativas e qualitativas tanto na pele perilesional como na pele não lesional. ${ }^{13}$

Desde a identificação do colágeno tipo VII como o maior componente das fibrilas de ancoragem, anticorpos, tanto monoclonais como policlonais, contra a proteína, como LH7:2 e L3d, foram desenvolvidos. Esses anticorpos são usados em estudos por microscopia eletrônica e/ou imunofluorescência. ${ }^{14}$ Poucos estudos ultra-estruturais, porém, têm sido feitos em lesões albopapulóides. ${ }^{15}$

O tratamento da EBD-AP é primariamente sintomático. Podem ser usados agentes orais como a vitamina $\mathrm{E}$, fenitoína, prednisolona, eritromicina, ciclosporina e tetraciclinas, que demonstraram resultados promissores em apenas alguns pacientes que fizeram uso por longo prazo desses medicamentos. No entanto, essa genodermatose é geralmente resistente ao tratamento. Agentes tópicos só têm sido eficazes na prevenção de infecções secundárias, porém existe o relato de melhora das lesões com uso de corticoterapia tópica, em pulsoterapia. ${ }^{2.9}$ No caso em questão, a paciente está em uso de vitamina E oral, $800 \mathrm{mg} /$ dia, e emolientes tópicos, com melhora discreta após dois meses de tratamento. described in the Brazilian literature by Silva in $1941 .{ }^{8}$

The lesions are characterized by blister formations, scarring and multiple white pruriginous papules. The blisters occur mainly at the extremities after minimal traumas. In the wound healing process of the blisters miliar and atrophic lesions appear. ${ }^{9}$ The papules develop in adolescence and may occur more prematurely. They predominate on the trunk (lombosacral region) and extremities, irrespective of blister emergence. ${ }^{2,10}$ The lesions are firm, perifollicular and ivory in color. They can measure up to $15 \mathrm{~mm}$ in diameter, and do not undergo spontaneous involution. ${ }^{10}$ In the case reported in this paper, the patient had albopapuloid lesions since infancy, in addition to (posttraumatic) blisters and scar lesions.

Oral and/or esophageal, though not cicatricial, erosion may occur. ${ }^{2,9}$ This was not observed in the case described.

In spite of dental alterations not occurring, the nails may be dystrophic or absent. ${ }^{2,9}$ The patient reported in this paper showed alterations only to the toenails.

While life expectancy is normal, spinocellular carcinoma may develop in the dystrophic areas. ${ }^{2}$ During the physical examination of the case reported, there were no lesions found that could be suggestive of malignancy.

Histopathology of the bullous lesion reveals only a subepidermal blister, ${ }^{11,12}$ as seen in the case described.

Many ultra-structural alterations in the anchoring fibrils have been previously reported in DEB, though none of them specifying a DEB subtype. In Pasini's albopapuloid variant, the anchoring fibrils show quantitative and qualitative abnormalities on the perilesional skin as well as the nonlesional skin. ${ }^{13}$

Ever since collagen type VII were identified as the major component of anchoring fibrils, monoclonal as well as polyclonal antibodies have been developed against proteins such as LH7:2 and L3d. These antibodies are used in electron microscope and immunofluorescence studies. ${ }^{14}$ However there have only been a few ultra-structural studies performed on albopapuloid lesions. ${ }^{15}$

Treament of $A P-D E B$ is primarily symptomatic. Oral agents may be used, such as vitamin E, phenytoin, prednisolone, erythromycin, cyclosporine and tetracyclines, all of which showed promising results in only the few patients who made long-term use of these medications. Yet this genodermatosis is usually resistant to treatment. Topical agents have been effective in preventing secondary infections. However, reports do exist on lesion improvement with use of topical corticosteroids in pulsotherapy ${ }^{2,9}$ In the case reported, the patient was in the process of taking vitamin E orally 800mg daily, and topical emollients. Discreet improvement occurred after two months of treatment. 


\section{REFERÊNCIAS / REFERENCES}

1. Lapinski P, Lapiere J-C. Sporadic dystrophic epidermolysis bullosa with concomitant atopic dermatitis. Br J Dermatol 1998;138:315-20.

2. Shenefelt PD, Castellano LM. Successful treatment of albopapuloid epidermolysis bullosa (Pasini's variant) with pulse topical corticosteroid therapy. J Am Acad Dermatol 1993;29:785-86.

3. Mellerio JE, Sallas-Alanis JC. A recurrent glycine substitution mutation, G2043R, in the type VII collagen gene (COL7a1) in dominant dystrophic epidermolysis bullosa. Br J Dermatol 1998;139:730-37.

4. Kon A, Nomura K. Novel glycine substitution mutations in COL7A1 reveal that the Pasini and Cockaine-Touraine variants of dominant dystrophic epidermolysis bullosa are allelic. J Invest Dermatol 1997;109:684-87.

5. Nomura K, Umeki K. Dominant dystrophic epidermolysis bullosa albopapuloidea Pasini -ultraestructural observations of albopapuloid lesions and a type VII collagen DNA polymorphism study of a family. Acta Derm Venerol 1997;77:277-80.

6. Hachisuka H, Yamamoto N. Proteoglycans in albopapuloid lesions of the Pasini form of dominant dystrophic epidermolysis bullosa. Kurume Med J 1995;42:1-8.

7. Pasini A. Dystrophie cutanee bulleuse atrophiante et albopapuloide. Ann Dermatol Syph 1928;9:1044-66.

8. Silva F. Epidermólise bolhosa distrófica (Epidermólise bolhosa de tendência cicatricial com cistos epidérmicos e formações albopapulóides). An bras Dermatol 1941;16:5-12.

9. Fine JD, Bauer EA. Revised clinical and laboratory criteria for subtypes of inherited epidermolysis bullosa. J Am Acad Dermatol
1991;24:119-35.

10. Ryan TJ, Wilkinson DS, eds. Textbook of Dermatology. 6th ed. 2001. Oxford: Blackwell; capítulo 40: 1817-43.

11. Lever WF, Schaumburg-Lever G. In: Histopathology of the Skin. 8th ed. 1997. Philadelphia: JB Lippincott; capítulo 6: 128-30. 12. Fitzpatrick TB, Freedberg IM. In: Dermatology in General Medicine. 5th ed. 1999; capítulo 65: 696-702.

13. McGrath JA, Schofield OMV, Eady RAJ. Epidermolysis bullosa pruriginosa: dystrophic epidermolysis bullosa with distinctive clinicopathological features. Br J Dermatol 1994;130:617-25. 14. The molecular genetics of dystrophic epidermolysis bullosa. Arch Dermatol 1993; 129:1566-70.

15. Nomura K, Umeki K, Sawamura D. Dominant dystrophic epidermolysis bullosa albopapuloidea Pasini- ultastructural observations of albopapuloid lesions and a type VII collagen DNA polymorphism study of a family. Acta Derm Venereol (Stockh) 1997; 77:277-80.

\footnotetext{
ENDEREÇO PARA CORRESPONDÊNCIA: / MAILING ADDRESS: Letícia Pereira Spinelli

Rua Carlos Vasconcelos 21 / 902 - Tijuca

Rio de Janeiro RJ 20521-050

Tel./Fax: (21) 2569-8679 / 2264-0116

E-mail: lspinelli@ieg.com.br
} 